\title{
A Novel Synthesis of 1,2,3-Benzotriazinones from 2-(o-Aminophenyl)oxazolines
}

\author{
Fernando Rocha-Alonzo, ${ }^{1}$ Daniel Chávez, ${ }^{2}$ Adrián Ochoa-Terán, ${ }^{2}$ David Morales-Morales, ${ }^{3}$ \\ Enrique F. Velázquez-Contreras, ${ }^{1}$ and Miguel Parra-Hake ${ }^{2}$ \\ ${ }^{1}$ Departamento de Ciencias Químico Biológicas, Universidad de Sonora, Hermosillo, SON, Mexico \\ ${ }^{2}$ Centro de Graduados e Investigación en Química, Instituto Tecnológico de Tijuana, Tijuana, BC, Mexico \\ ${ }^{3}$ Instituto de Química, Universidad Nacional Autónoma de México, Ciudad de México, Mexico \\ Correspondence should be addressed to Fernando Rocha-Alonzo; fernando.rocha@guayacan.uson.mx
}

Received 29 September 2016; Accepted 13 December 2016; Published 19 January 2017

Academic Editor: Hakan Arslan

Copyright (C) 2017 Fernando Rocha-Alonzo et al. This is an open access article distributed under the Creative Commons Attribution License, which permits unrestricted use, distribution, and reproduction in any medium, provided the original work is properly cited.

1,2,3-Benzotriazinones were synthesized in excellent yields by the reaction of 2-(o-aminophenyl)oxazolines and isoamyl nitrite in methanol. The crystal structure of the acetyl derivative of one of the 1,2,3-benzotriazinones provided additional support for the spectroscopic structural characterization of the title compounds.

\section{Introduction}

1,2,3-Benzotriazinones are compounds widely investigated due to their interesting biological and chemical properties. These heterocyclic compounds have been studied as anaesthetic [1], anti-inflammatory [2], anticancer [3, 4], and antitumoral $[5,6]$ agents. In organic synthesis, triazinones are used as an activating moiety in coupling agents for the preparation of peptides and amino acids [7-9]. As a result of their biological and synthetic importance, there is still interest in the development of methods for the synthesis of compounds which contain the 1,2,3-triazinone moiety.

In general, 1,2,3-benzotriazinones are prepared via intramolecular cyclization through diazonium ion condensation with an adjacent nucleophilic function. Using this strategy, 1,2,3-triazinones have been obtained from aminobenzamides [10-12], aminonitriles [13, 14], and triazenes [15-17]. Other workers have reported the synthesis of 1,2,3-benzotriazinones by the oxidation of indazol-3-amines with hydrogen peroxide in the presence of sodium carbonate, though in low yields, and by the cyclization of 2-azido-N-4-toluoylbenzamide in moderate yields [18].
In this report, we describe facile access to the title compounds from chiral and nonchiral 2-(o-aminophenyl)oxazolines. Since racemization is not possible during the reaction, this method allows the preparation of enantiopure 1,2,3benzotriazinones in excellent yields.

\section{Results and Discussion}

The first step for the synthesis of 1,2,3-benzotriazinones was the preparation of 2-(o-aminophenyl)oxazolines $\mathbf{3 a}-\mathbf{3 c}$ (see (1)). These oxazolines were prepared in high yields (58$80 \%$ ) by cyclization of anthranilonitrile with ethanolamines under basic conditions in a mixture of glycerol and ethylene glycol, following the methodology reported by Gómez and coworkers [19]. In the literature, it has been reported that oxazolines $\mathbf{3 a}$ and $\mathbf{3 b}$ were obtained as oils, whereas in our work both were isolated as solids; we believe this fact is due to problems in the purification process in the previous report. Nevertheless, NMR and IR spectroscopic and mass spectrometry data are consistent with those previously reported [20]. 


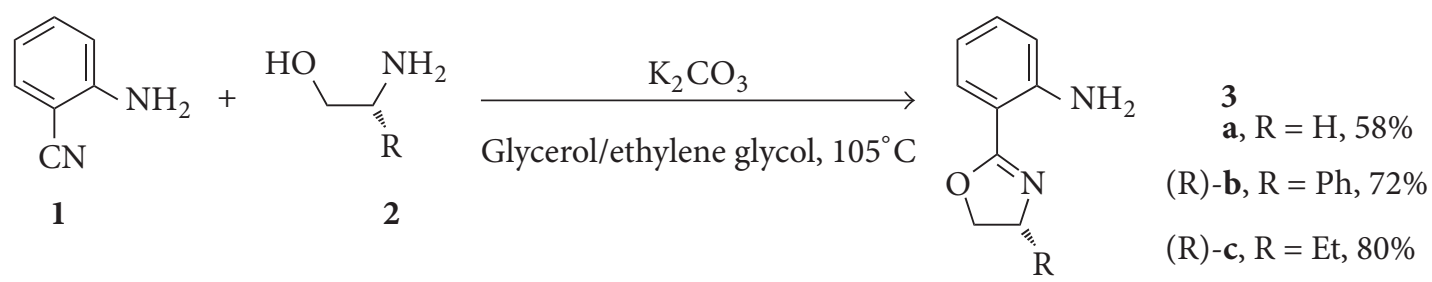

Once the necessary 2-(o-aminophenyl)oxazolines were obtained, the next step was the synthesis of the 1,2,3benzotriazinones $\mathbf{4 a - 4 c}$. Compounds $\mathbf{4 a - 4 c}$ were synthesized by diazotization reaction involving oxazolines $3 \mathbf{a}-$ $3 c$ and methanolic isoamyl nitrite. In all cases, the new 1,2,3-benzotriazinones were obtained in quantitative yields (Scheme 1).

It is assumed that the reaction takes place by the intermediacy of the diazonium ion 5 formed from 2-(oaminophenyl)oxazoline (3) using a large excess of isoamyl nitrite in order to ensure formation of the diazonium salt (Scheme 1). The electron withdrawing effect of the diazonium group in $\mathbf{5}$ could promote oxazolinyl ring hydrolysis, taking water from the alcoholic media, and producing the 2carbamoylbenzenediazonium 6 . The 1,2,3-triazinone moiety in 4 is then achieved by ring closure between the amide and the adjacent diazonium group in $\mathbf{6}$. Similar mechanistic assumptions were proposed by Colomer and Moyano in the synthesis of this kind of compound from aminonitriles [13, 21].

Infrared spectroscopy of compounds $\mathbf{4 a - 4 c}$ showed a single band at ca. $(\nu) 3430 \mathrm{~cm}^{-1}$ due to the $\mathrm{O}-\mathrm{H}$ stretching; the bands at ca. $(\nu) 1687 \mathrm{~cm}^{-1}$ and at ca. (v) $1657 \mathrm{~cm}^{-1}$ correspond to the $\mathrm{N}=\mathrm{N}$ and the $\mathrm{C}=\mathrm{O}$ stretching, respectively. ${ }^{1} \mathrm{H}$ NMR spectroscopy showed the following: aromatic hydrogen from the 1,2,3-benzotriazinone moiety appeared as an $\mathrm{ABCD}$ system with the characteristic two doublets and two triplets between 8.29 and 7.87 ppm, slightly shifted to lower field relative to the 2-(o-aminophenyl)oxazolines; aliphatic protons appeared between 6.39 and $0.90 \mathrm{ppm}$. For compound $\mathbf{4 b}$, the phenyl protons are at $(\delta) 7.43 \mathrm{ppm}$. ${ }^{13} \mathrm{C}$ NMR spectroscopy showed carbonyl carbon at ca. $(\delta)$ $156.5 \mathrm{ppm}$; aromatic carbon appeared in the range 146.1$120.3 \mathrm{ppm}$ and aliphatic carbon in the range $64.2-10.8 \mathrm{ppm}$. The proton of hydroxyl group in the proposed structure was not identified by ${ }^{1} \mathrm{H}$ NMR, but the carbinol moiety was inferred from the chemical shifts on ${ }^{13} \mathrm{C}$ NMR data. Since compounds $\mathbf{4 a - 4 c}$ are novel, high-resolution mass spectrometry was run with no significant difference between calculated and obtained values (less than $\pm 0.003 \mathrm{amu}$ ). In general, the molecular formula assignment and the spectroscopic characterization were consistent with their structures.

In order to corroborate the presence of the hydroxyl group, the acetyl derivative $7 \mathbf{a}$ was obtained by reaction of $\mathbf{4 a}$ with acetic anhydride in pyridine (see (2)). NMR spectra for the acetyl derivative 7 a turned out to be similar to $4 \mathbf{a}$, but with new signals for the acetyl moiety at $\delta_{\mathrm{H}} 1.95$ and $\delta_{\mathrm{C}} 21.5$ for the methyl group and $\delta_{\mathrm{C}} 171.9$ for the ester carbonyl.

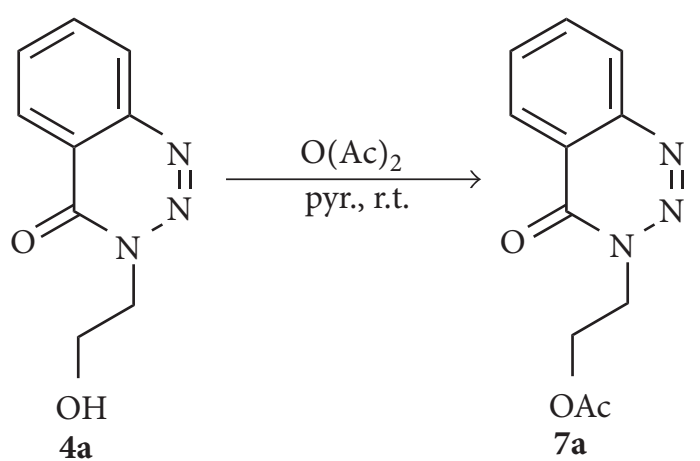

Suitable crystals for X-ray diffraction studies of 1,2,3benzotriazinone 7 a were grown by slow vapor diffusion of hexane into a saturated solution in ethyl acetate. Compound $7 \mathbf{a}$ crystallized in the triclinic system with the space group $\mathrm{P} \overline{\mathrm{i}}$. Molecular structure of 1,2,3-benzotriazinone $7 \mathbf{a}$ is shown in Figure 1, which confirms the presence of the 1,2,3-triazinone system and indirectly corroborates the hydroxyl group in 1,2,3-benzotriazinones $\mathbf{4 a - 4 c}$.

In the molecular structure of $7 \mathbf{a}$, the $\mathrm{N} 1=\mathrm{N} 2$ bond [1.2715(19) $\AA$ ] is longer than the typical value for $\mathrm{N}=\mathrm{N}$ double bond (1.236 $\AA$ ) [22], whereas the N2-N3 bond [1.3728(19) $\AA$ ] is slightly shorter than the typical value for $\mathrm{N}-\mathrm{N}$ single bond (1.404 $\AA$ ) [22]. The structure shows coplanarity between the two rings. These data are in agreement with crystal structure reports of related 1,2,3-benzotriazinones [17, 2325]. Crystallographic data of $\mathbf{7 a}$ are included as supplementary material (in Supplementary Material available online at https://doi.org/10.1155/2017/2384780).

Of interest to pharmaceutical applications, Reingruber et al. have suggested that the coplanar structure in 1,2,3benzotriazinones could have DNA-intercalating abilities such as those displayed by some anticancer agents [17].

In summary, we have presented an efficient method for the synthesis of 1,2,3-benzotriazinones from 2-(o-aminophenyl)oxazolines in high yields.

\section{Experimental Section}

3.1. General Procedures. All reagents were purchased in the highest quality available and were used without further purification. The solvents used in column chromatography were obtained from commercial suppliers and used without 


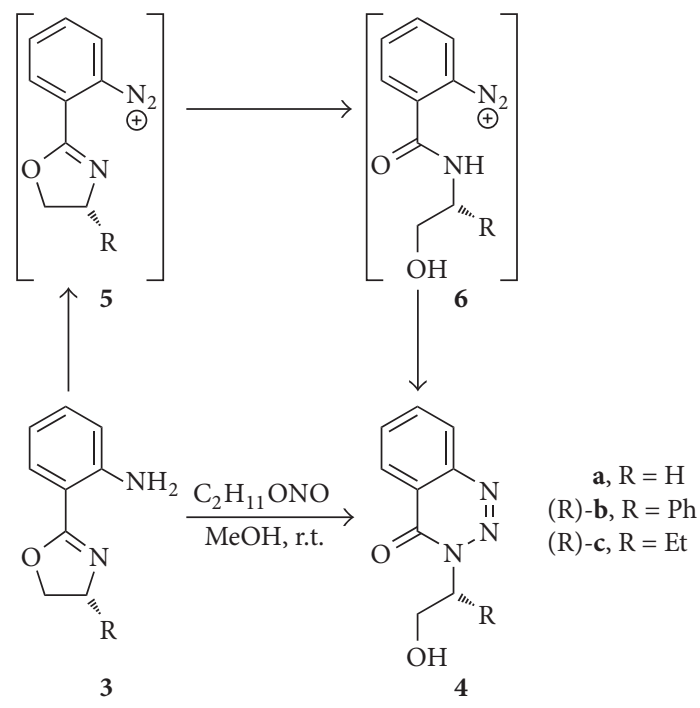

Scheme 1: Synthesis of 1,2,3-benzotriazinones $\mathbf{4 a - 4 c .}$

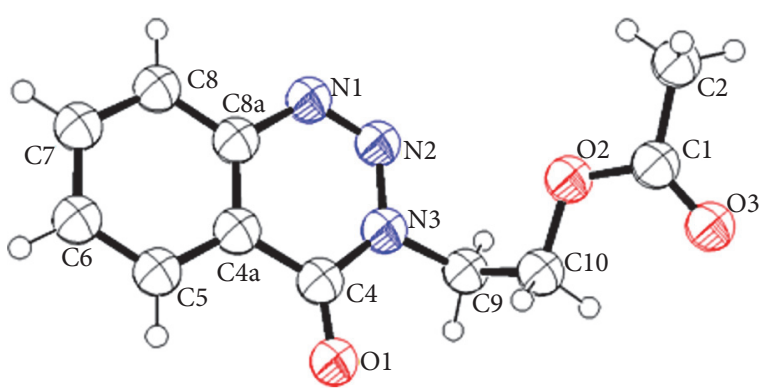

FIGURE 1: Molecular structure of 7a (ORTEP drawing showing 50\% ellipsoids).

distillation. Infrared spectra (FTIR) were recorded on a Perkin Elmer FT-IR 1600 spectrophotometer. Nuclear magnetic resonance ${ }^{1} \mathrm{H}$ (at $200 \mathrm{MHz}$ ) and ${ }^{13} \mathrm{C}$ (at $50 \mathrm{MHz}$ ) spectra were recorded on a Varian Mercury $200 \mathrm{MHz}$ spectrometer in $\left(\mathrm{CD}_{3}\right)_{2} \mathrm{CO}$ with TMS as internal standard. Melting points were obtained on an Electrothermal 88629 apparatus. Optical rotations were determined using an Autopol III polarimeter. EIMS were recorded on an Agilent Technologies 5975C mass spectrometer. The ESI-HRMS data were performed at HighResolution Mass Spectrometry Facility, UC Riverside.

3.2. General Procedure for the Synthesis of 2-(o-Aminophenyl)Oxazoline (3). Anthranilonitrile (1 equiv.), potassium carbonate ( 0.1 equiv.), and ethanolamine (1.7 equiv.) were placed in a Schlenk flask, followed by a solution of glycerol in dry ethylene glycol (5:9) $(3.3 \mathrm{~mL}$ of solution per mmol of anthranilonitrile). The resulting mixture was stirred at $105^{\circ} \mathrm{C}$ under argon until the disappearance of the nitrile (followed by TLC, hexane/ethyl acetate, $3: 1$ ). The mixture was cooled to room temperature and then poured over crushed ice. The resulting white solid was filtered and then dissolved in dichloromethane. The organic solution was washed with water, dried over anhydrous $\mathrm{Na}_{2} \mathrm{SO}_{4}$, and filtered, and the solvent was evaporated under reduced pressure to give a crude product that was purified by flash chromatography on neutral alumina (hexane/ethyl acetate, $20: 1$ ) to give the pure product.

2-[4,5-Dihydro-1,3-oxazol-2-yl]aniline (3a). White solid (58\% yield), mp 52-53 ${ }^{\circ} \mathrm{C}$. FTIR (KBr): $\nu$ 3384, 3264, 1630, $1254 \mathrm{~cm}^{-1} .{ }^{1} \mathrm{H}$ NMR $\left[\left(\mathrm{CD}_{3}\right)_{2} \mathrm{CO}, 200 \mathrm{MHz}\right]: \delta 7.69(\mathrm{dd}, J=$ $7.9,1.7 \mathrm{~Hz}, 1 \mathrm{H}), 7.19$ (ddd, $J=8.3,7.1,1.6 \mathrm{~Hz}, 1 \mathrm{H}), 6.66(\mathrm{~m}$, $2 \mathrm{H}), 6.04(\mathrm{~s}, 2 \mathrm{H}), 4.30(\mathrm{~m}, 2 \mathrm{H}), 4.08(\mathrm{~m}, 2 \mathrm{H}) .{ }^{13} \mathrm{C} \mathrm{NMR}$ $\left[\left(\mathrm{CD}_{3}\right)_{2} \mathrm{CO}, 50 \mathrm{MHz}\right]: \delta 164.4,148.1,131.6,129.3,115.7,115.4$, 108.9, 65.6, 54.8. EI-MS (Int. \%): [M] ${ }^{+} 162$ (100), 131 (36), 118 (33).

2-[(4R)-4-Phenyl-4,5-dihydro-1,3-oxazol-2-yl]aniline (3b). Yellow solid (72\% yield), mp 62-63 ${ }^{\circ} \mathrm{C} .[\alpha]_{20}^{D}=-182$ (c 0.22, $\mathrm{MeOH})$. FTIR (KBr): $v 3416,3272,1631,1249 \mathrm{~cm}^{-1} .{ }^{1} \mathrm{H}$ NMR $\left[\left(\mathrm{CD}_{3}\right)_{2} \mathrm{CO}, 200 \mathrm{MHz}\right]: \delta 7.70(\mathrm{dd}, J=8.0,1.8 \mathrm{~Hz}, 1 \mathrm{H}), 7.32$ $(\mathrm{m}, 5 \mathrm{H}), 7.21(\mathrm{ddd}, J=8.4,7.0,1.4 \mathrm{~Hz}, 1 \mathrm{H}), 6.83(\mathrm{dd}, J=8.6$, $0.8 \mathrm{~Hz}, 1 \mathrm{H}$ ), 6.80 (br. s, $2 \mathrm{H}$ ), 6.60 (ddd, $J=8.2,7.0,1.2 \mathrm{~Hz}, 1 \mathrm{H})$, $5.43(\mathrm{dd}, J=10.0,8.2 \mathrm{~Hz}, 1 \mathrm{H}), 4.66(\mathrm{dd}, J=10.0,8.3 \mathrm{~Hz}, 1 \mathrm{H})$, $4.11(\mathrm{dd}, J=8.2,8.2 \mathrm{~Hz}, 1 \mathrm{H}) .{ }^{13} \mathrm{C} \mathrm{NMR}\left[\left(\mathrm{CD}_{3}\right)_{2} \mathrm{CO}, 50 \mathrm{MHz}\right]$ : $\delta$ 165.0, 148.8, 142.7, 132.3, 129.8, 128.7, 127.5, 126.6, 116.0, 115.7, 108.6, 73.0, 70.2. EI-MS (Int. \%): [M] 238 (100), 207 (48), 118 (50).

2-[(4R)-4-Ethyl-4,5-dihydro-1,3-oxazol-2-yl]aniline (3c). Brown oil $\left(80 \%\right.$ yield). $[\alpha]_{20}^{D}=+10(c 0.22, \mathrm{MeOH})$. FTIR $(\mathrm{NaCl}): v$ $3461,3286,1632,1263 \mathrm{~cm}^{-1} .{ }^{1} \mathrm{H}$ NMR $\left[\left(\mathrm{CD}_{3}\right)_{2} \mathrm{CO}, 200 \mathrm{MHz}\right]$ : $\delta 7.62(\mathrm{dd}, J=7.9,1.6 \mathrm{~Hz}, 1 \mathrm{H}), 7.15(\mathrm{ddd}, J=8.0,6.0,2.0 \mathrm{~Hz}$, $1 \mathrm{H}), 6.77$ (dd, $J=8.5,0.7 \mathrm{~Hz}, 1 \mathrm{H}), 6.74$ (br. s, $2 \mathrm{H}$ ), 6.55 (ddd, $J=8.2,7.0,1.2 \mathrm{~Hz}, 1 \mathrm{H}), 4.28(\mathrm{~m}, 2 \mathrm{H}), 3.90(\mathrm{~m}, 1 \mathrm{H}), 1.59(\mathrm{~m}$, $2 \mathrm{H}), 0.97(\mathrm{t}, J=7.4 \mathrm{~Hz}, 3 \mathrm{H}) .{ }^{13} \mathrm{C} \mathrm{NMR}\left[\left(\mathrm{CD}_{3}\right)_{2} \mathrm{CO}, 50 \mathrm{MHz}\right]$ : $\delta$ 164.1, 150.3, 132.4, 130, 116.1, 115.4, 109, 70.8, 68.8, 29.5, 10.4. EI-MS (Int. \%): [M] ${ }^{+} 190$ (81), 161 (100), 133 (59), 118 (31).

3.3. General Procedure for the Synthesis of 1,2,3-Benzotriazinones. To a solution of 2-(o-aminophenyl)oxazoline (3) (1 equiv.) in methanol, a solution of isoamyl nitrite (8 equiv.) in methanol was added. The reaction mixture was stirred at room temperature until the disappearance of the aniline (followed by TLC, hexane/ethyl acetate, $3: 1$ ). The solvent was evaporated under reduced pressure to give a crude product that was purified by washing with petroleum ether and recrystallization from hexane/ethyl acetate.

3-(2-Hydroxyethyl)-1,2,3-benzotriazin-4(3H)-one (4a). White solid (>99\% yield), mp 111-112 ${ }^{\circ} \mathrm{C}$. FTIR (KBr): $v$ 3431, 1691, $1646,1300 \mathrm{~cm}^{-1} .{ }^{1} \mathrm{H}$ NMR $\left[\left(\mathrm{CD}_{3}\right)_{2} \mathrm{CO}, 200 \mathrm{MHz}\right]: \delta 8.29$ (ddd, $J=7.8,1.5,0.7 \mathrm{~Hz}, 1 \mathrm{H}), 8.15$ (ddd, $J=8.1,1.5,0.6 \mathrm{~Hz}$, $1 \mathrm{H}), 8.06$ (ddd, $J=8.1,7.0,1.5 \mathrm{~Hz}, 1 \mathrm{H}), 7.91(\mathrm{ddd}, J=7.9$, $6.9,1.6 \mathrm{~Hz}, 1 \mathrm{H}), 4.57(\mathrm{t}, J=5.6 \mathrm{~Hz}, 2 \mathrm{H}), 4.02(\mathrm{t}, J=5.6 \mathrm{~Hz}$, $2 \mathrm{H}) .{ }^{13} \mathrm{C}$ NMR $\left[\left(\mathrm{CD}_{3}\right)_{2} \mathrm{CO}, 50 \mathrm{MHz}\right]: \delta 157.1,146.1,136.8$, 134.2, 129.8, 126.5, 121.7, 61.2, 54.1. ESI-HRMS: 192.0778 (100), calculated for $[\mathrm{M}+\mathrm{H}]^{+}, \mathrm{C}_{9} \mathrm{H}_{10} \mathrm{~N}_{3} \mathrm{O}_{2}, 192.0768$.

3-((R)-2-Hydroxy-1-phenylethyl)-1,2,3-benzotriazin-4(3H)-one (4b). White solid (>99\% yield), mp $79-80^{\circ} \mathrm{C} .[\alpha]_{20}^{D}=-183$ (c $0.22, \mathrm{MeOH})$. FTIR (KBr): v 3419, 1683, 1661, $1294 \mathrm{~cm}^{-1}$. 
${ }^{1} \mathrm{H}$ NMR [ $\left.\left(\mathrm{CD}_{3}\right)_{2} \mathrm{CO}, 200 \mathrm{MHz}\right]: \delta 8.27$ (ddd, $J=7.8,1.5$, $0.6 \mathrm{~Hz}, 1 \mathrm{H}), 8.16$ (ddd, $J=8.1,1.3,0.6 \mathrm{~Hz}, 1 \mathrm{H}), 8.04$ (ddd, $J=8.1,7.1,1.5 \mathrm{~Hz}, 1 \mathrm{H}), 7.87$ (ddd, $J=7.8,7.1,1.3 \mathrm{~Hz}, 1 \mathrm{H}), 7.43$ $(\mathrm{m}, 5 \mathrm{H}), 6.39(\mathrm{dd}, J=9.7,5.2 \mathrm{~Hz}, 1 \mathrm{H}), 4.70(\mathrm{dd}, J=11.4$, $9.7 \mathrm{~Hz}, 1 \mathrm{H}), 4.25(\mathrm{dd}, J=11.4,5.2 \mathrm{~Hz}, 1 \mathrm{H}) .{ }^{13} \mathrm{C} \mathrm{NMR}$ [( $\left.\left.\mathrm{CD}_{3}\right)_{2} \mathrm{CO}, 50 \mathrm{MHz}\right]: \delta 156.1,144.6,138.6,136.0,133.3,129.4$, $128.9,128.9,128.7,125.7,120.5,64.0,63.3$. ESI-HRMS: 268.1094 (100), calculated for $[\mathrm{M}+\mathrm{H}]^{+}, \mathrm{C}_{15} \mathrm{H}_{14} \mathrm{~N}_{3} \mathrm{O}_{2}, 268.1081$.

3-((R)-1-Hydroxybutan-2-yl)-1,2,3-benzotriazin-4(3H)-one (4c). White solid (>99\% yield), mp $89-90^{\circ} \mathrm{C}$. $[\alpha]_{20}^{D}=-5$ (c 0.22 , $\mathrm{MeOH})$. FTIR (KBr): $\nu 3439,1686,1663,1296 \mathrm{~cm}^{-1} \cdot{ }^{1} \mathrm{H}$ NMR $\left[\left(\mathrm{CD}_{3}\right)_{2} \mathrm{CO}, 200 \mathrm{MHz}\right]: \delta 8.29(\mathrm{ddd}, J=7.9,1.5,0.6 \mathrm{~Hz}, 1 \mathrm{H})$, 8.16 (ddd, $J=8.1,1.5,0.6 \mathrm{~Hz}, 1 \mathrm{H}), 8.07$ (ddd, $J=8.2,7.0$, $1.5 \mathrm{~Hz}, 1 \mathrm{H}), 7.91(\mathrm{ddd}, J=7.9,7.0,1.5 \mathrm{~Hz}, 1 \mathrm{H}), 5.22(\mathrm{~m}, 1 \mathrm{H})$, $4.10(\mathrm{dd}, J=11.3,8.4 \mathrm{~Hz}, 1 \mathrm{H}), 3.96(\mathrm{dd}, J=11.3,5.1 \mathrm{~Hz}$, $1 \mathrm{H}), 1.99$ (quin, $J=7.4 \mathrm{~Hz}, 2 \mathrm{H}), 0.90(\mathrm{t}, J=7.4 \mathrm{~Hz}, 3 \mathrm{H}) .{ }^{13} \mathrm{C}$ NMR $\left[\left(\mathrm{CD}_{3}\right)_{2} \mathrm{CO}, 50 \mathrm{MHz}\right]: \delta 156.6,144.5,135.8,133.2,128.8$, 125.7, 120.3, 64.2, 62.3, 24.2, 10.8. ESI-HRMS: 220.1091 (100), calculated for $[\mathrm{M}+\mathrm{H}]^{+}, \mathrm{C}_{11} \mathrm{H}_{14} \mathrm{~N}_{3} \mathrm{O}_{2}, 220.1081$.

3.4. Procedure for the Synthesis of Acetylated Derivative 3(2-Hydroxyethyl)-1,2,3-benzotriazin-4(3H)-onyl Acetate (7a). To a solution of 1,2,3-benzotriazinone (4a) $(200 \mathrm{mg}, 1.0 \mathrm{mmol}$ in $3.0 \mathrm{~mL}$ pyridine), excess of acetic anhydride $(3.0 \mathrm{~mL}$, $32 \mathrm{mmol}$ ) was added. The reaction mixture was stirred at room temperature for $24 \mathrm{~h}$. To purify the acetylated derivative $7 \mathrm{a}$, sodium hydroxide $(2.6 \mathrm{~g}, 64 \mathrm{mmol}$ in $30 \mathrm{~mL}$ of water) was added to the reaction mixture and then extracted with ethyl acetate $(3 \times 10 \mathrm{~mL})$. The organic phase was washed with $2 \mathrm{M}$ $\mathrm{HCl}(3 \times 40 \mathrm{~mL})$, dried over anhydrous sodium sulfate, and filtered. The solvent was evaporated under reduced pressure and the white solid dried in vacuum for $24 \mathrm{~h}$.

A white solid was obtained $(240 \mathrm{mg}, 1.0 \mathrm{mmol}$, quantitative yield). FTIR (KBr): $v$ 3072, 1741, 1685, $1230 \mathrm{~cm}^{-1} .{ }^{1} \mathrm{H}$ $\mathrm{NMR}\left[\left(\mathrm{CD}_{3}\right)_{2} \mathrm{CO}, 200 \mathrm{MHz}\right]: \delta 8.30(\mathrm{ddd}, J=7.8,1.5$, $0.6 \mathrm{~Hz}), 8.17(\mathrm{ddd}, J=8.1,1.6,0.6 \mathrm{~Hz}), 8.09(\mathrm{ddd}, J=8.1,7.0$, $1.5 \mathrm{~Hz}), 7.93$ (ddd, $J=7.8,6.9,1.6 \mathrm{~Hz}), 4.70(\mathrm{t}, J=5.6 \mathrm{~Hz}, 2 \mathrm{H})$, $4.55(\mathrm{t}, J=5.6 \mathrm{~Hz}, 2 \mathrm{H}), 1.95(\mathrm{~s}, 3 \mathrm{H}) .{ }^{13} \mathrm{C} \mathrm{NMR}\left[\left(\mathrm{CD}_{3}\right)_{2} \mathrm{CO}\right.$, $50 \mathrm{MHz}]: \delta 171.9,157.0,146.0,136.9,134.4,130.0,126.5,121.6$, $63.0,50.4,21.5$.

X-Ray Data Collection and Refinement. The details of the structure determination are given in Table S1, atomic coordinates are given in Table S2, and bond lengths $(\AA)$ and angles $\left({ }^{\circ}\right)$ are given in Table S3 in Supporting Information. Crystallographic data for the structural analyses have been deposited with the Cambridge Crystallographic Data Centre CCDC 903418. Further details of the crystal structure investigation are available free of charge via https://www.ccdc.cam.ac.uk/conts/retrieving.html (or from the CCDC, 12 Union Road, Cambridge CB2 1EZ, UK; fax: +44 1223 336033; e-mail: deposit@ccdc.cam.ac.uk).

\section{Competing Interests}

The authors declare that there are no competing interests regarding the publication of this paper.

\section{Acknowledgments}

The authors gratefully acknowledge support from Consejo Nacional de Ciencia y Tecnología (CONACyT Grant 36435-E and "Supramolecular Chemistry Thematic Network" Grant 271884), Programa de Mejoramiento del Profesorado (Apoyo a la Incorporación de Nuevos PTC Grant Promep/103.5/11/4462), and Consejo del Sistema Nacional de Educación Tecnológica (COSNET, Grant 486-02-P). The authors are indebted to Ignacio Rivero Espejel and Ratnasamy Somanathan for their support in this work.

\section{References}

[1] G. Caliendo, F. Fiorino, P. Grieco et al., "Preparation and local anaesthetic activity of benzotriazinone and benzoyltriazole derivatives," European Journal of Medicinal Chemistry, vol. 34, no. 12, pp. 1043-1051, 1999.

[2] G. Z. Zheng, P. Bhatia, J. Daanen et al., "Structure-activity relationship of triazafluorenone derivatives as potent and selective mGluR1 antagonists," Journal of Medicinal Chemistry, vol. 48, no. 23, pp. 7374-7388, 2005.

[3] A. Vaisburg, N. Bernstein, S. Frechette et al., "(2-Aminophenyl)-amides of $\omega$-substituted alkanoic acids as new histone deacetylase inhibitors," Bioorganic \& Medicinal Chemistry Letters, vol. 14, no. 1, pp. 283-287, 2004.

[4] A.-M. Chollet, T. Le Diguarher, N. Kucharczyk et al., "Solidphase synthesis of $\alpha$-substituted 3-bisarylthio N-hydroxy propionamides as specific MMP inhibitors," Bioorganic \& Medicinal Chemistry, vol. 10, no. 3, pp. 531-544, 2002.

[5] T. Le Diguarher, A.-M. Chollet, M. Bertrand et al., "Stereospecific synthesis of 5-substituted 2-bisarylthiocyclopentane carboxylic acids as specific matrix metalloproteinase inhibitors," Journal of Medicinal Chemistry, vol. 46, no. 18, pp. 3840-3852, 2003.

[6] A. S. Clark, B. Deans, M. F. G. Stevens et al., "Antitumor imidazotetrazines. 32. Synthesis of novel imidazotetrazinones and related bicyclic heterocycles to probe the mode of action of the antitumor drug temozolomide," Journal of Medicinal Chemistry, vol. 38, no. 9, pp. 1493-1504, 1995.

[7] L. A. Carpino, J. Xia, C. Zhang, and A. El-Faham, "Organophosphorus and nitro-substituted sulfonate esters of 1-hydroxy-7azabenzotriazole as highly efficient fast-acting peptide coupling reagents," Journal of Organic Chemistry, vol. 69, no. 1, pp. 62-71, 2004.

[8] V. Janout, B. Jing, I. V. Staina, and S. L. Regen, "Selective transport of ATP across a phospholipid bilayer by a molecular umbrella," Journal of the American Chemical Society, vol. 125, no. 15, pp. 4436-4437, 2003.

[9] T. M. Gierasch, M. Chytil, M. T. Didiuk et al., "A modular synthetic approach toward exhaustively stereodiversified ligand libraries," Organic Letters, vol. 2, no. 25, pp. 3999-4001, 2000.

[10] T. Okuzumi, E. Nakanishi, T. Tsuji, and S. Makino, "Efficient solid-phase synthesis of diverse 1,2,3-benzotriazin-4-ones using tert-butyl nitrite," Tetrahedron Letters, vol. 44, no. 29, pp. 5539$5542,2003$.

[11] A. Deeb, M. Kotb, and M. El-Abbasy, "Pyridazine derivatives and related compounds, part 12: synthesis of some pyridazino $\left[4^{\prime}, 3^{\prime}: 4,5\right]$ thieno[3,2-d]-1,2,3-triazines," Phosphorus, Sulfur, and Silicon and the Related Elements, vol. 180, no. 2, pp. 591-599, 2005. 
[12] K. M. Dawood, A. M. Farag, and N. A. Khedr, "Facile route to novel 2-pyridone, pyrazolo[3,4-d]-1,2,3-triazine, and pyrazolo[3,4-d]- and [1,5-a]-pyrimidine derivatives," Arkivoc, vol. 2008, no. 15, pp. 166-175, 2008.

[13] J. P. Colomer and E. L. Moyano, "New application of heterocyclic diazonium salts. Synthesis of pyrazolo[3,4-d][1,2,3]triazin-4-ones and imidazo[4,5-d][1,2,3] triazin-4-ones," Tetrahedron Letters, vol. 52, no. 14, pp. 1561-1565, 2011.

[14] M. Tišler and B. Stanovnik, "Heterocyclic diazo compounds as starting materials in organic synthesis (review)," Chemistry of Heterocyclic Compounds, vol. 16, no. 5, pp. 443-463, 1980.

[15] C. Gil and S. Bräse, "Solid-phase synthesis of biologically active benzoannelated nitrogen heterocycles: an update," Journal of Combinatorial Chemistry, vol. 11, no. 2, pp. 175-197, 2009.

[16] C. Gil, A. Schwögler, and S. Bräse, “The Synthesis of 3-Substituted 6-Aryl-3 H-benzo[a][1,2,3]triazinones Using PolymerBound Triazenes," Journal of Combinatorial Chemistry, vol. 6, no. 1, pp. 38-42, 2004.

[17] R. Reingruber, S. Vanderheiden, T. Muller, M. Nieger, M. EsSayed, and S. Bräse, "Efficient synthesis of substituted 3-acyl3,4-dihydrobenzo[d][1,2,3]triazines," Tetrahedron Letters, vol. 50, no. 26, pp. 3439-3442, 2009.

[18] H. Döpp and D. Döpp, "Product class 2: six-membered hetarenes with three heteroatoms," in Science of Synthesis, Chapter 17: Category 2, Hetarenes and Related Ring Systems, 2004.

[19] M. Gómez, S. Jansat, G. Muller, G. Aullón, and M. A. Maestro, "Ruthenium complexes containing chiral N-donor ligands as catalysts in acetophenone hydrogen transfer-new amino effect on enantioselectivity," European Journal of Inorganic Chemistry, vol. 2005, no. 21, pp. 4341-4351, 2005.

[20] A. S. Gajare, N. S. Shaikh, G. K. Jnaneshwara, V. H. Deshpande, T. Ravindranathan, and A. V. Bedekar, "Clay catalyzed conversion of isatoic anhydride to 2-(o-aminophenyl)oxazolines," Journal of the Chemical Society, Perkin Transactions 1, no. 6, pp. 999-1001, 2000.

[21] E. L. Moyano, J. P. Colomer, and G. I. Yranzo, "New application of heterocyclic diazonium salts: synthesis of new pyrazolo[3,4d] $[1,2,3]$ triazin-4-ones," European Journal of Organic Chemistry, vol. 2008, no. 19, pp. 3377-3381, 2008.

[22] F. H. Allen, O. Kennard, D. G. Watson, L. Brammer, A. G. Orpen, and R. Taylor, "Tables of bond lengths determined by $\mathrm{x}$-ray and neutron diffraction. Part 1 . Bond lengths in organic compounds," Journal of the Chemical Society, Perkin Transactions 2, no. 12, pp. S1-S19, 1987.

[23] W. E. Hunt, C. H. Schwalbe, and K. Vaughan, "3-Hydroxy-1,2,3benzotriazin-4(3H)-one, $\mathrm{C}_{7} \mathrm{H}_{5} \mathrm{~N}_{3} \mathrm{O}_{2}$," Acta Crystallographica Section C, vol. 39, no. 6, pp. 738-740, 1983.

[24] J. Hjortås, "The crystal and molecular structure of 1,2,3benzotriazin-4(3H)-one," Acta Crystallographica Section B Structural Crystallography and Crystal Chemistry, vol. 29, no. 9, pp. 1916-1922, 1973.

[25] F. Rocha-Alonzo, G. Aguirre, and M. Parra-Hake, "N-(2-Hydroxy-ethyl)-2-[3-(p-tol-yl)triazen-1-yl]benzamide," Acta Crystallographica Section E, vol. 65, no. 5, pp. o990-0991, 2009. 

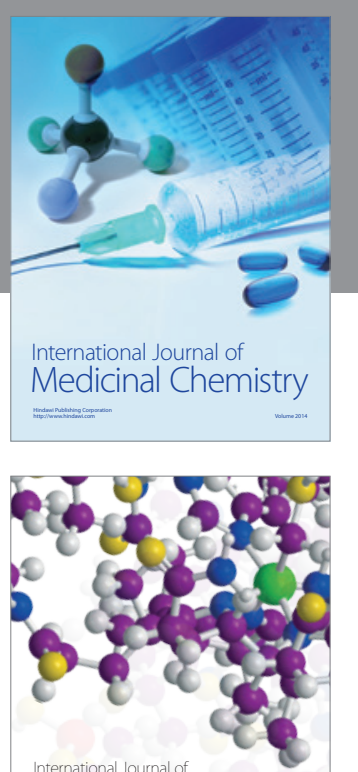

Carbohydrate Chemistry

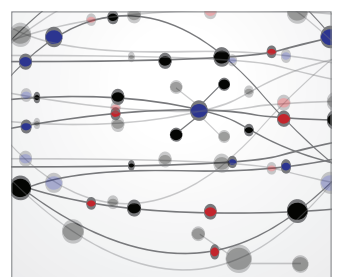

The Scientific World Journal
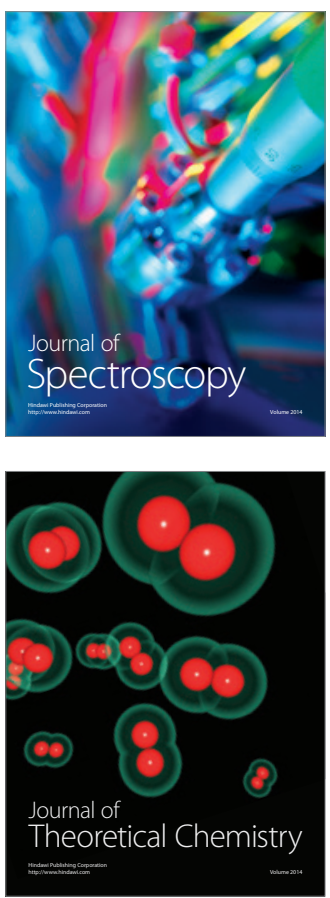
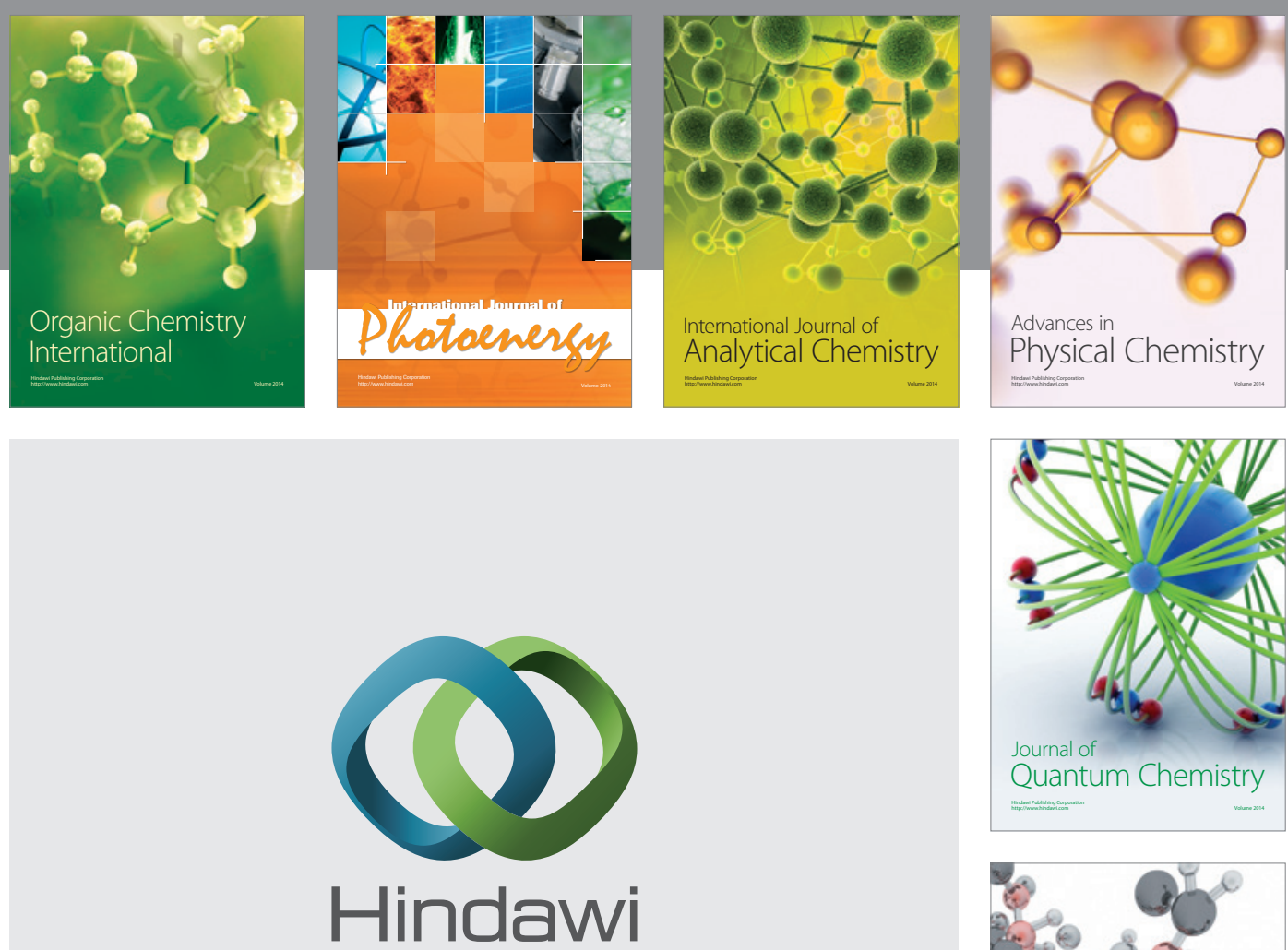

Submit your manuscripts at

https://www.hindawi.com

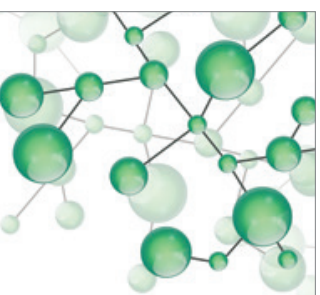

International Journal of

Inorganic Chemistry
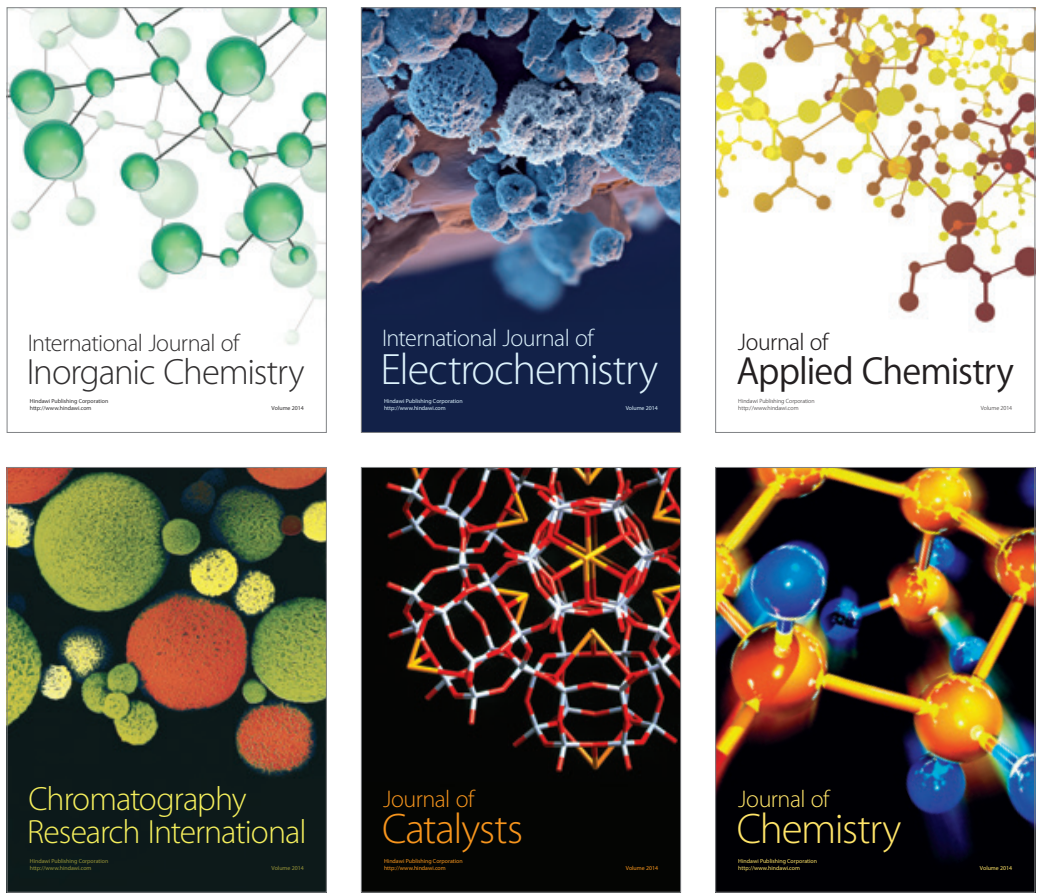

Journal of

Applied Chemistry
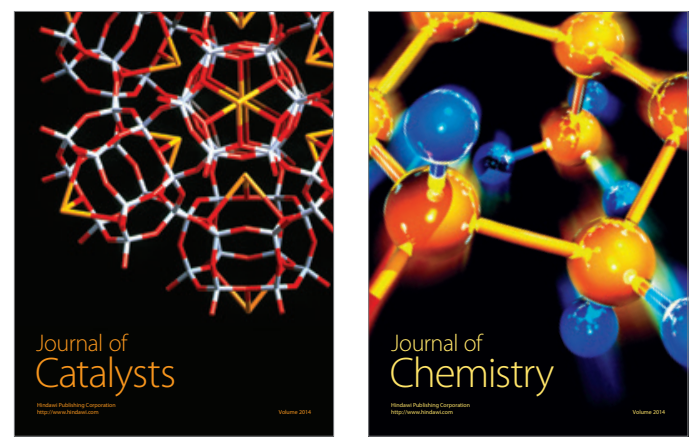
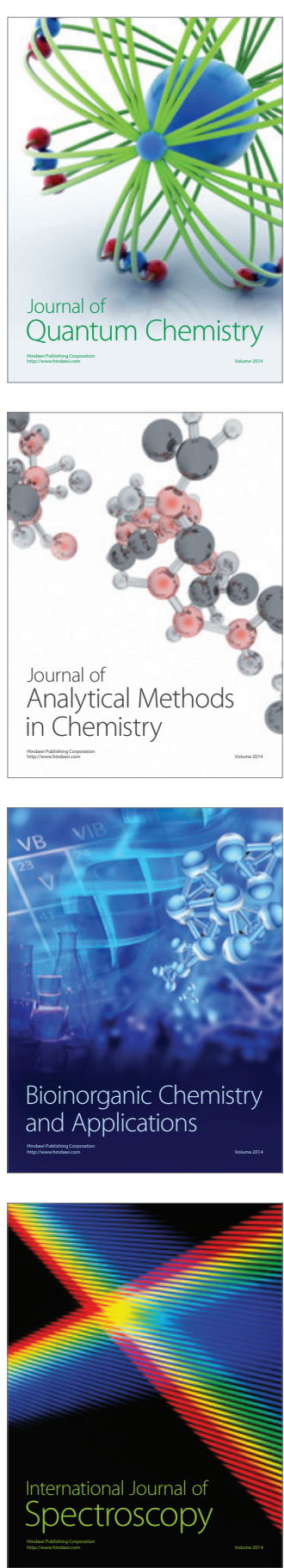